\title{
WEEDS OCCURRENCE AND IMPORTANCE UNDER DISTINCT INTERCROPPING SYSTEMS ${ }^{1}$
}

\author{
Ocorrência e Importância de Plantas Daninhas sob Sistemas de Consorciação de Cultivos
}

\author{
CONCENÇO, G. ${ }^{2}$, CECCON, G. ${ }^{3}$, SCHWERZ, F. ${ }^{4}$, FONSECA, I.C. ${ }^{4}$ and LEITE, L.F. ${ }^{4}$
}

\begin{abstract}
Intercropping systems involving corn are often subjected to stress caused by weeds, which usually result in 30-70 per cent yield loss when no control practice is applied. This study aimed to assess the composition of weed communities due to soil coverage, at neighboring areas submitted to distinct soil managements. The soil was collected at field and the study was conducted under a greenhouse in three steps: (1) weeds composition and importance within each treatment; (2) comparison between treatments (distinct crop and intercropping managements); (3) infestation in the area as a whole. The weed composition in the short term is influenced by the management of the area, but this shift requires some more years to be reflected at the soil seed bank. Some weed species occur in high densities and even this way they may not be the most serious weed species present in a given field. Just a few species are adapted to a given system of management in a level enough to be a troublesome weed. Areas differed in relation to weed infestation as a function of management adopted and number of years the new management was applied.
\end{abstract}

Keywords: soil coverage, soil management, phytosociology.

\begin{abstract}
RESUMO - Sistemas de consórcios de cultivos envolvendo o cultivo do milho podem ser afetados pela infestação de plantas daninhas, que podem causar entre 30 e $70 \%$ de redução na produtividade caso práticas de controle destas espécies não sejam adotadas. Objetivouse com este estudo avaliar a composição florística em função da cobertura do solo, em áreas adjacentes submetidas a manejos distintos. Amostras de solo em cada área foram coletadas e levadas a casa de vegetação, onde o ensaio foi instalado e avaliado em três etapas: (1) composição florística e importância de cada espécie em cada tratamento; (2) comparação entre tratamentos (distintos manejos de consórcios); (3) infestação da área como um todo. A composição florística de curto prazo é influenciada pelo manejo da área, mas esta alteração necessita de alguns anos para ser refletida no banco de sementes do solo. Algumas espécies ocorrem em maior densidade, e mesmo assim podem não ser plantas daninhas problemáticas naquela área. Apenas certas espécies estão adaptadas a determinados sistemas de manejo em nivel que as tornem plantas daninhas problemáticas. Áreas diferiram quanto a composição florística em função do manejo adotado e número de anos de aplicação deste manejo.
\end{abstract}

Palavras-chave: cobertura do solo, manejo do solo, fitossociologia

\section{INTRODUCTION}

The need for cropping systems aiming at better soil and biodiversity conservation while keeping high yields and profitability, made the direct seeding system widespread in the
Brazilian Cerrado (Savanna-like) region. In less than 30 years Brazil has turned itself from a food importer into one of the world's great breadbaskets (Brazilian..., 2010), in part due to the advancement of agriculture in the Cerrado, where most of the area is planted at

1 Recebido para publicação em 16.2.2011 e aprovado em 19.4.2011.

2 Agronomist, Ph.D., Weed Science, researcher at Embrapa Western Region Agriculture, Dourados-MS, Brazil, <germani@cpao.embrapa.br>; ${ }^{3}$ Agronomist, Ph.D., Water \& Soil Conservation, researcher at Embrapa Western Agriculture, DouradosMS, Brazil, <gessi@cpao.embrapa.br>; ${ }^{4}$ Agronomist, trainee at Embrapa Western Agriculture, Dourados-MS, Brazil. 
the no-till cropping system. In this region, the presence of a well defined dry season and high temperatures during most of the year, restricts the formation and maintenance on soil (Kluthcouski \& Aidar, 2003).

Often associated to direct-seeding practices, intercropping is the agricultural principle of growing two or more crops in the same area at the same cropping season (Andrews \& Kassam, 1976). The main purpose of intercropping is to produce a greater yield and liquid income on a given piece of land by making use of resources in the way of maximum efficiency (Gharineh \& Moosavi, 2010).

Recently, the principle of intercropping is also including other agricultural practices than just growing grain crops. The croplivestock integration (CLI) has contributed to the advancement of agricultural systems in the Cerrado. Thus, CLI, through intercropping of annual crops and plants for cover or grazing, ensures a more efficient use of water, as well as weed suppression by cultural means, reducing costs with chemical control of weeds (Pacheco et al., 2009).

Corn based intercropping systems are often subjected to severe stress offered by weeds (Hugar \& Palled, 2008), which usually result in an average of 30-70 per cent yield loss when no control practice is applied (Fernandez et al., 2008). Under crop-livestock integration, the reduction in occurrence of weed species is reflected in the soil seed bank more efficiently than when using only herbicides for weed control due to grazing - which usually does not affect dormant seeds in soil. In addition, this integration makes possible to manage the resistance of some weeds to herbicides, once grazing is almost a non-selective method of weed control (Voll et al., 2005).

Understanding not only the level of occurrence but also the composition of the weed community under each cropping system is important to achieve efficient weed control. Research data show that crop management systems with low soil disturbance allow changes at the weed seed bank in soil. Under no-till systems, the presence of straw from previous crops is important for reducing the percentage of emergence of some weed species while it may increase the occurrence of others (Voll et al., 2005; Fernandez et al., 2008).

This study aimed to assess the composition of weed communities due to soil coverage, at neighboring areas submitted to distinct soil managements.

\section{MATERIAL AND METHODS}

The trial was installed under a greenhouse with soil samples collected at the first $15 \mathrm{~cm}$ of soil, from neighboring agricultural areas at the Experimental Field of Embrapa Western Region Agriculture (Embrapa-CPAO), in Dourados city, Mato Grosso do Sul state, Brazil. All areas are under the same climatic conditions with similar soil characteristics, differentiated only by the management adopted in the last three years, as described in Table 1.

Phytosociological characterization of weed species emerged from soil seed bank was carried out with undisturbed soil carefully collected in the field and deposited in plastic buckets with capacity of $5 \mathrm{~L}$ and diameter of $0,245 \mathrm{~m}$, in each one of the treatments previously characterized in Table 1 . The original straw coverage present at the area by the time of the sampling was also maintained at the greenhouse. After soil sampling, experimental unities were taken to the greenhouse and distributed in benches in a completely randomized design with four replications. Soybean was planted in all buckets, being thinned to two soybean plants per plot after emergence. This practice aimed to simulate the shading caused by crop plants under field conditions (around 424.000 plants per hectare). Soil moisture was continuously maintained around $70 \%$ of field capacity. Soils were sampled twenty days after sowing. All the seedlings emerged were identified, collected, and the dry mass was determined by species and treatment.

For each species present, estimations of relative frequency, relative dominance and relative abundance were done. These variables describe the relationship of each species with the others in the same area (Mueller-Dombois \& Ellenberg, 1974). The Importance Value Index (I.V.I.), that describes which species are the most important within the studied area, 
Table 1 - Treatments evaluated at the trial. Embrapa Western Region Agriculture, Dourados, MS, Brazil, 2010

\begin{tabular}{|c|c|c|c|}
\hline & Description of treatment & & Description of treatment \\
\hline \multirow[t]{2}{*}{$\mathrm{T} 1$} & $\begin{array}{l}1 \mathrm{DBP} \rightarrow \text { Area with } 15 \text { year old } B \text {. decumbens grown in } \\
\text { monocropping desiccated } 1 \text { day before planting soybean } \\
\text { (planting over Brachiaria straw) }\end{array}$ & $\mathrm{T} 4$ & $\begin{array}{l}\text { 1DBP } \rightarrow \text { Area with six months old B. brizanta (cv. } \\
\text { Piatã) intercropped with corn, desiccated } 1 \text { day before } \\
\text { planting soybean (planting over Brachiaria }+ \text { corn straw) }\end{array}$ \\
\hline & $\begin{array}{l}15 \mathrm{DBP} \rightarrow \text { Area with } 15 \text { year old } B . \text { decumbens grown in } \\
\text { monocropping desiccated } 15 \text { days before planting soybean } \\
\text { (planting over Brachiaria straw) }\end{array}$ & & $\begin{array}{l}15 \mathrm{DBP} \rightarrow \text { Area with six months old } B . \text { brizanta }(\mathrm{cv} . \\
\text { Piatã) intercropped with corn, desiccated } 15 \text { days before } \\
\text { planting soybean (planting over Brachiaria }+ \text { corn straw) }\end{array}$ \\
\hline \multirow[t]{2}{*}{$\mathrm{T} 2$} & $\begin{array}{l}1 \mathrm{DBP} \rightarrow \text { Area with one year old } B \text {. decumbens grown in } \\
\text { monocropping desiccated } 1 \text { day before planting soybean } \\
\text { (planting over Brachiaria straw) }\end{array}$ & $\mathrm{T} 5$ & $\begin{array}{l}1 \mathrm{DBP} \rightarrow \text { Area with six months old } \text { B. ruziziensis } \\
\text { intercropped with corn, desiccated } 1 \text { day before planting } \\
\text { soybean (planting over Brachiaria }+ \text { corn straw) }\end{array}$ \\
\hline & $\begin{array}{l}15 \mathrm{DBP} \rightarrow \text { Area with one year old } B . \text { decumbens grown in } \\
\text { monocropping desiccated } 15 \text { days before planting soybean } \\
\text { (planting over Brachiaria straw) }\end{array}$ & & $\begin{array}{l}15 \mathrm{DBP} \rightarrow \text { Area with six months old } B \text {. ruziziensis } \\
\text { intercropped with corn, desiccated } 15 \text { days before } \\
\text { planting soybean (planting over Brachiaria }+ \text { corn straw) }\end{array}$ \\
\hline \multirow[t]{2}{*}{$\mathrm{T} 3$} & $\begin{array}{l}1 \mathrm{DBP} \rightarrow \text { Area with six months old } B . \text { decumbens } \\
\text { intercropped with corn desiccated } 1 \text { day before planting } \\
\text { soybean (planting over Brachiaria }+ \text { corn straw) }\end{array}$ & T6 & $\begin{array}{l}\mathrm{S} \rightarrow \text { Area where a fresh mass shoot of a six months old } \\
B . \text { decumbens, was deposited at the soil surface (roots } \\
\text { were removed) - (planting over Brachiaria shoot straw) }\end{array}$ \\
\hline & $\begin{array}{l}15 \mathrm{DBP} \rightarrow \text { Area with six months old } B \text {. decumbens } \\
\text { intercropped with corn, desiccated } 15 \text { days before planting } \\
\text { soybean (planting over Brachiaria }+ \text { corn straw) }\end{array}$ & & $\begin{array}{l}\mathrm{R} \rightarrow \text { Area where fresh mass roots of a six months old } \\
B . \text { decumbens, was deposited at the soil surface (shoot } \\
\text { was removed) - (planting over Brachiaria roots straw) }\end{array}$ \\
\hline
\end{tabular}

NOTE: From T1 to T5, the same treatments were replicated with distinct desiccation periods before planting (Brachiaria plants desiccated with glyphosate 1 or 15 days before planting soybeans); T6 is composed by soil covered by dry mass of either shoot or roots of $B$. decumbens only. DBP: days before planting.

was also determined according to MuellerDombois \& Ellenberg formulas (1974). After these analyses, areas were compared by the Sørensen's (1957) similarity coefficient in a way to estimate the current degree of weeds similarity between areas after three years of distinct managements.

Data was analyzed in three steps: (1) weeds composition and importance within each treatment (characterization of the treatment); (2) comparison between treatments (distinct crop and intercropping managements); (3) infestation in the area as a whole, once all treatments were in neighboring areas. This aimed to characterize the average weed composition and density in the area where treatments were installed. Data were presented in tables with the appropriate phytosociological coefficients, and graphs with standard deviations were used to analyze data between treatments.

\section{RESULTS AND DISCUSSION}

The area where the trial was installed was used for agriculture in the last 20 years, most of the time under no-till cropping systems. The main crops grown at this area were corn, soybean, sunflower and forage species (Brachiaria spp.). On the previous year of the installation of the trial - except for treatment 1 , the area was planted with soybeans, and in succession corn intercropped with Brachiaria (according to the treatments) was planted. The study was conducted at the soil seed bank present at this area, which is a result of the overall management the area was submitted throughout the last years.

At treatment 1 - area with fifteen year old Brachiaria decumbens grown alone, $B$. decumbens and Amaranthus hybridus were the most abundant and the most dominant weed species. However, Chamaesyce hyssopifolia was more frequently seen than A. hybridus. When considering all phytosociological coefficients together, $B$. decumbens, $A$. hybridus and $C$. hyssopifolia were the most troublesome weeds at the long-term livestock area (Table 2). At treatment 2 - area with one year old $B$. decumbens grown alone, once again $B$. decumbens and A. hybridus were the most abundant and dominant weed species, and also the weed species most frequently seen. The three most troublesome weed species in the short-term livestock area were $B$. decumbens and 
A. hybridus, followed by Commelina benghalensis in third place, which was significantly more abundant $(2,98)$ than the remainder of the species, which averaged 0,43 of abundance (Table 3).

When comparing treatments 1 and 2, long and short term livestock areas, it can be inferred that the number of weed species present at the former (12) was twice the number observed at the latter (6). This is according to Voll et al. (2005) and Correia \& Dirugan (2004), who stated that management systems with low soil disturbance usually allow formation of a bigger and more diverse weed seed bank in soil. However, the same authors highlight that the diversity is not directly related to higher infestation levels. This can be observed on Figures 1, 2 and 3, where T1, even with a relatively higher number of weed species present (Table 2) in relation to T2 (Table 3), showed around $8 \%$ of its area covered by weeds while T2 showed 30\% of its area covered by these plants (Figure 1). In addition, the same tendency was observed for number of plants of weed species (Figure 2), around 90 plants per square meter at T1 and around 400 plants per square meter at T2. For dry mass accumulation (Figure 3), around $1,8 \mathrm{~g} \mathrm{~m}^{-2}$ was accumulated by weeds at $\mathrm{T} 1$ while around $6 \mathrm{~g} \mathrm{~m}^{-2}$ was accumulated by weeds at T2.

The above presented results illustrate that long-term fallow areas tend to present a more diverse plant composition (Hugar \& Palled, 2008), seriously reducing the occurrence of problematic weed species usually present in

Table 2 - Phytosociology of species at treatment 1. Embrapa Western Region Agriculture, Dourados, MS, Brazil, 2010

\begin{tabular}{|l|c|r|r|r|}
\hline \multicolumn{1}{|c|}{ Plant species } & Relat. abund. & Relat. freq. & Relat. domin. & IV.I \\
\hline Amaranthus hybridus & 10.42 & 10.53 & 11.71 & 32.65 \\
\hline Ambrosia elatior & 2.08 & 5.26 & 1.01 & 8.36 \\
\hline Brachiaria decumbens & 52.08 & 21.05 & 59.68 & 132.81 \\
\hline Brachiaria plantaginea & 4.17 & 5.26 & 4.47 & 13.90 \\
\hline Chamaesyce hyssopifolia & 8.33 & 15.79 & 4.94 & 29.06 \\
\hline Conyza bonariensis & 2.08 & 5.26 & 0.91 & 8.26 \\
\hline Digitaria horizontalis & 6.25 & 10.53 & 4.94 & 21.72 \\
\hline Echinochloa crusgalli & 2.08 & 5.26 & 3.07 & 10.42 \\
\hline Eleusine indica & 2.08 & 5.26 & 1.07 & 8.42 \\
\hline Leonotis nepetifolia & 4.17 & 5.26 & 6.48 & 15.91 \\
\hline Richardia brasiliensis & 4.17 & 5.26 & 0.84 & 10.27 \\
\hline Sida rhombifolia & 2.08 & 5.26 & 0.88 & 8.22 \\
\hline- Total (\%) & 100 & 100 & 100 & 300 \\
\hline
\end{tabular}

Rel. abund. = relative abundance of the weed species; Rel. freq. = relative frequency of appearance of the weed species; Rel. dom. $=$ relative dominance of the weed species; IVI = Importance Value Index of the species based on the three previous parameters.

Table 3 - Phytosociology of species at treatment 2. Embrapa Western Region Agriculture, Dourados, MS, Brazil, 2010

\begin{tabular}{|l|c|c|r|r|}
\hline \multicolumn{1}{|c|}{ Plant species } & Relat. abund. & Relat. freq. & Relat. domin. & IV.I \\
\hline Amaranthus hybridus & 19.15 & 36.84 & 4.66 & 60.65 \\
\hline Brachiaria decumbens & 76.60 & 42.11 & 92.51 & 211.21 \\
\hline Brachiaria plantaginea & 0.43 & 5.26 & 0.34 & 6.03 \\
\hline Chamaesyce hyssopifolia & 0.43 & 5.26 & 0.63 & 6.32 \\
\hline Commelina benghalensis & 2.98 & 5.26 & 1.72 & 9.96 \\
\hline Richardia brasiliensis & 0.43 & 5.26 & 0.14 & 5.83 \\
\hline \multicolumn{1}{|c|}{ Total (\%) } & 100 & 100 & 100 & 300 \\
\hline
\end{tabular}

Rel. abund. $=$ relative abundance of the weed species; Relat. freq. $=$ relative frequency of appearance of the weed species; Rel. dom. $=$ relative dominance of the weed species; IVI = Importance Value Index of the species based on the three previous parameters. 


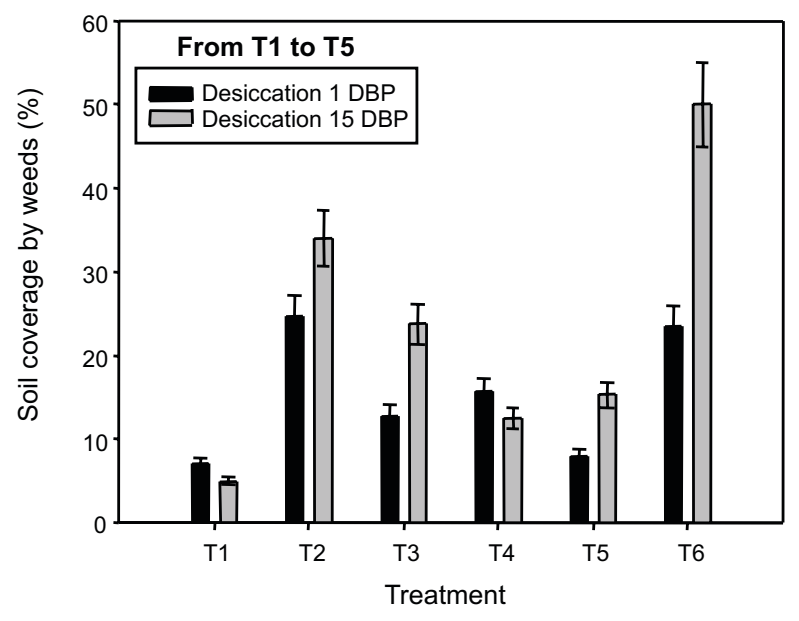

Figure 1 - Soil covered by weeds per treatment. Embrapa Western Region Agriculture, Dourados, MS, Brazil, 2010.

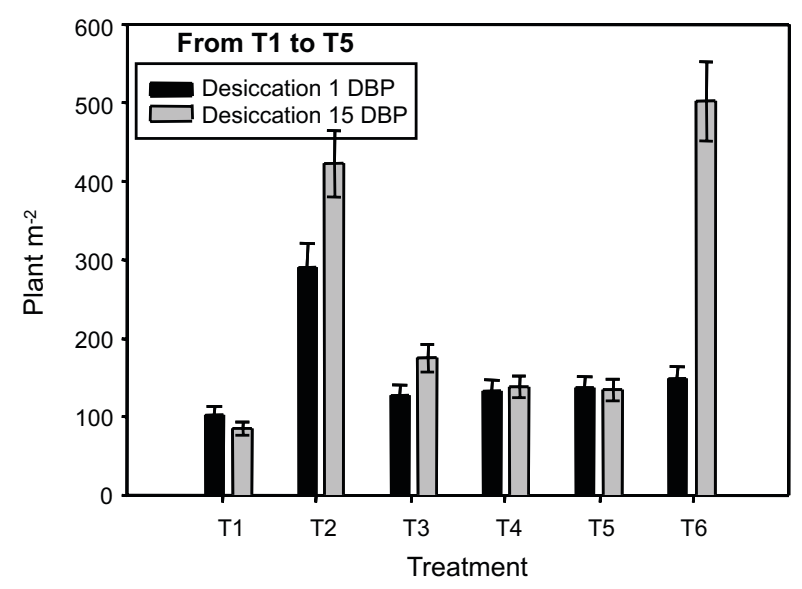

Figure 2 - Number of plants per treatment. Embrapa Western Region Agriculture, Dourados, MS, Brazil, 2010.

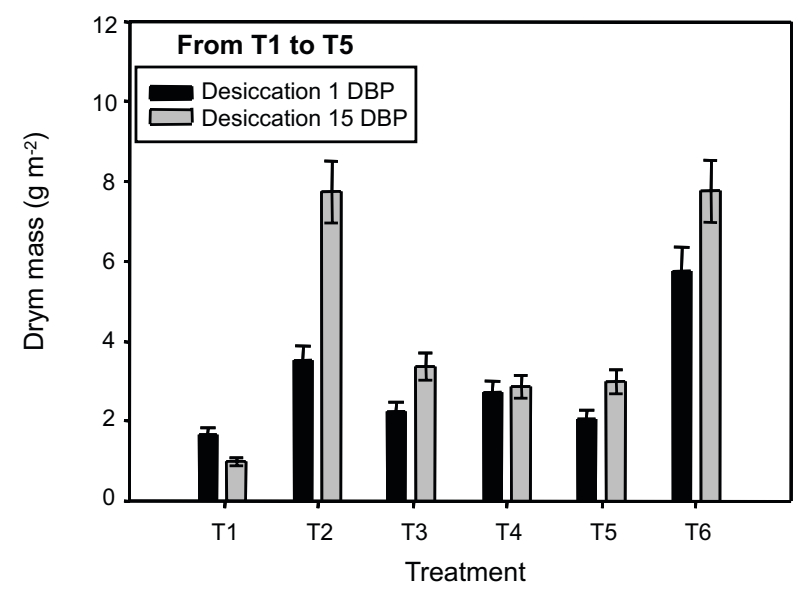

Figure 3 - Dry mass of weeds per treatment. Embrapa Western Region Agriculture, Dourados, MS, Brazil, 2010. areas where the same crop is grown year after year in absence of crop rotation or succession. Besides that, the integration of uses in the same area - like crop-livestock integration, also contributes for the same variability in terms of plant composition in the area and equalization of the soil seed bank (Fernandez et al., 2008).

From T3 to T5 treatments are very similar, varying only the species of forage grown in the area. When $B$. decumbens was grown (T3 -

4), Echinochloa crusgalli and Digitaria horizontalis were the most abundant, frequent and dominant species, although $A$. hybridus and $A$. elatior presented similar frequency to the former two species. The most important species at this treatment were E. crusgalli, Digitaria horizontalis and A. hybridus. When Brachiaria brizantha cv. Piatã was grown (T4 Table 5), D. horizontalis and Portulaca oleracea were the most abundant species, Amaranthus hybridus and $D$. horizontalis the most frequent ones, and $D$. horizontalis and $B$. plantaginea the most dominant weed species. D. horizontalis, A. hybridus and B. plantaginea were the most important ones at the balance of the three factors studied. When $B$. ruziziensis was grown (T5 - Table 6), A. hybridus and B. decumbens were the most abundant, $A$. hybridus and $D$. horizontalis the most frequently seen, and $B$. decumbens and $A$. hybridus the most dominant ones. Putting the three factors together (abundance, frequency and dominance), A. hybridus, B. decumbens and D. horizontalis were the most problematic weed species at the area.

When these three treatments (T3, T4, T5) are pool analyzed, $A$. hybridus, $D$. horizontalis and E. crusgalli are ranked in order as the most problematic weed species, being all of them present at the three treatments. In addition, the first two are also ranked between the most important weeds individually in each one of the three treatments.

Correia \& Durigan (2004) studied the effects of mulching on the emergence of Brachiaria decumbens, Digitaria horizontalis, Sida spinosa, Ipomoea grandifolia, Ipomoea hederifolia and Ipomoea quamoclit and found that shading caused inhibitory effect on seedling emergence of $B$. decumbens and $D$. horizontalis. At least one of these two weed 
Table 4 - Phytosociology of species at treatment 3. Embrapa Western Region Agriculture, Dourados, MS, Brazil, 2010

\begin{tabular}{|l|c|c|c|c|}
\hline \multicolumn{1}{|c|}{ Plant species } & Relat. abund. & Relat. freq. & Relat. domin. & IVI \\
\hline Amaranthus hybridus & 20.14 & 15.63 & 15.35 & 51.11 \\
\hline Ambrosia elatior & 6.94 & 15.63 & 4.37 & 26.94 \\
\hline Bidens pilosa & 3.47 & 6.25 & 3.30 & 13.03 \\
\hline Brachiaria decumbens & 3.47 & 3.13 & 3.82 & 10.42 \\
\hline Brachiaria plantaginea & 0.69 & 3.13 & 0.28 & 4.10 \\
\hline Chamaesyce hyssopifolia & 2.08 & 6.25 & 1.00 & 9.33 \\
\hline Digitaria horizontalis & 21.53 & 15.63 & 26.55 & 63.71 \\
\hline Echinochloa crusgalli & 22.92 & 15.63 & 32.41 & 70.96 \\
\hline Eleusine indica & 1.39 & 6.25 & 0.58 & 8.22 \\
\hline Emilia sonchifolia & 10.42 & 3.13 & 8.53 & 22.07 \\
\hline Leonotis nepetifolia & 3.47 & 3.13 & 1.14 & 7.74 \\
\hline Portulaca oleracea & 2.08 & 3.13 & 1.26 & 6.46 \\
\hline Richardia brasiliensis & 1.39 & 3.13 & 1.40 & 5.92 \\
\hline \multicolumn{1}{|c|}{ Total (\%) } & 100 & 100 & 100 & 300 \\
\hline
\end{tabular}

Rel. abund. $=$ relative abundance of the weed species; Relat. freq. $=$ relative frequency of appearance of the weed species; Rel. dom. $=$ relative dominance of the weed species; IVI = Importance Value Index of the species based on the three previous parameters.

Table 5 - Phytosociology of species at treatment 4. Embrapa Western Region Agriculture, Dourados, MS, Brazil, 2010

\begin{tabular}{|l|c|c|c|c|}
\hline \multicolumn{1}{|c|}{ Plant species } & Relat. abund. & Relat. freq. & Relat. domin. & IVI \\
\hline Amaranthus hybridus & 21.05 & 25.93 & 8.92 & 55.89 \\
\hline Ambrosia elatior & 7.89 & 7.41 & 5.08 & 20.38 \\
\hline Brachiaria decumbens & 7.02 & 3.70 & 0.74 & 11.46 \\
\hline Brachiaria plantaginea & 7.02 & 7.41 & 15.28 & 29.71 \\
\hline Chamaesyce hyssopifolia & 0.88 & 3.70 & 0.89 & 5.47 \\
\hline Digitaria horizontalis & 27.19 & 18.52 & 46.16 & 91.87 \\
\hline Echinochloa crusgalli & 9.65 & 11.11 & 5.26 & 26.02 \\
\hline Eleusine indica & 1.75 & 7.41 & 1.40 & 10.56 \\
\hline Portulaca oleracea & 11.40 & 7.41 & 12.29 & 31.10 \\
\hline Richardia brasiliensis & 6.14 & 7.41 & 4.00 & 17.54 \\
\hline Total (\%) & 100 & 100 & 100 & 300 \\
\hline
\end{tabular}

Rel. abund. = relative abundance of the weed species; Rel. freq. = relative frequency of appearance of the weed species; Rel. dom. $=$ relative dominance of the weed species; IVI = Importance Value Index of the species based on the three previous parameters.

Table 6 - Phytosociology of species at treatment 5. Embrapa Western Region Agriculture, Dourados, MS, Brazil, 2010

\begin{tabular}{|l|c|c|r|r|}
\hline \multicolumn{1}{|c|}{ Plant species } & Relat. abund. & Relat. freq. & Relat. domin. & IV I \\
\hline Amaranthus hybridus & 50.54 & 35.00 & 37.77 & 123.31 \\
\hline Ambrosia elatior & 1.08 & 5.00 & 0.77 & 6.84 \\
\hline Brachiaria decumbens & 19.35 & 10.00 & 44.01 & 73.36 \\
\hline Digitaria horizontalis & 12.90 & 20.00 & 8.00 & 40.90 \\
\hline Echinochloa crusgalli & 4.30 & 10.00 & 2.26 & 16.56 \\
\hline Eleusine indica & 9.68 & 10.00 & 3.75 & 23.43 \\
\hline Portulaca oleracea & 2.15 & 10.00 & 3.44 & 15.59 \\
\hline \multicolumn{1}{|c|}{ Total (\%) } & 100 & 100 & 100 & 300 \\
\hline
\end{tabular}

Rel. abund. = relative abundance of the weed species; Rel. freq. = relative frequency of appearance of the weed species; Rel. dom. $=$ relative dominance of the weed species; IVI. = Importance Value Index of the species based on the three previous parameters. 
species was present among the most important weeds in every treatment of this trial. This means that (1) the straw resulting from plants desiccation was not homogeneously distributed at the soil surface, (2) the amount of straw present $\left(\mathrm{t} \mathrm{ha}^{-1}\right)$ was not enough to promote physical inhibition of emergence of these species, or (3) the density of these weed species was too high and the prevention of access to light was not enough for its occurrence at considerable density. Besides the physical effect, allelopathic effect by the decomposing straw of forage species after desiccation is proved to suppress the development of some important weed species (Luz et al., 2010).

When comparing T3 (B. decumbens), T4 (B. brizantha Piatã) and T5 (B. ruziziensis), desiccated 15 or 1 DBP (days before planting), in relation to area of soil covered by weeds, it is possible to infer that the area at T3 desiccated 15 DBP presented relatively higher part of its area covered by weeds in comparison to the same treatment desiccated $1 \mathrm{DBP}$, and $\mathrm{T} 4$ and T5, independently of the desiccation time. This is probably due to a supposed smaller soil coverage promoted by this species (Figure 1), because the number of weed plants per square meter at this treatment was slightly higher than at T4 and T5 (Figure 2). This means that $B$. decumbens may be allowing more immediate emergence of weed seedlings after desiccation due probably to a smaller soil coverage which could be caused either by a native smaller dry mass accumulation or by a faster degradation of the dry mass produced. The dry mass accumulated by weeds was similar between these treatments (Figure 3), being slightly higher at T3 desiccated 15 DBP, in accordance to soil coverage (Figure 1).

The percentage of area covered by a given species, weedy or not, usually determines the richness of the plant community at the area (Townsend et al., 2009). For example, plants with $\mathrm{C}_{4}$ carbon metabolism usually grow faster than plants with $\mathrm{C}_{3}$ carbon metabolism under conditions of high temperature and radiation availability (Taiz \& Zeiger, 2006). However, this higher capacity of dry mass accumulation in $\mathrm{C}_{4}$ species has an additional energetic cost. This translates to say that, if a community composed mainly by $\mathrm{C}_{3}$ species is able to establish first in a given area, it will prevent $\mathrm{C}_{4}$ species of having enough sunlight and suppress its development. The canopy which is able to develop first and make use of the available space will determine the composition of species present in a given weed or mixed plant community (Silva et al., 2007).

In this case, among other factors, the farmer should consider choosing the forage species which usually promotes the better soil coverage in order to prevent access of seedlings of weed species to light. Based on the occurrence of $B$. plantaginea at T4 (Table 5) and $B$. decumbens at T5 (Table 6) among the most important weed species, it should be highlighted that in areas where grain crops are rotated with livestock, seedlings of species used as forage may be a potential problem when infesting the crop in succession. Besides presenting better soil coverage, the choice of a forage species more easily controlled by the appropriate pre-planting management (usually chemical desiccation), may be important to avoid verifying infestation of the forage species inside the successional crop (Severino, 2005).

Treatment 6 was not intra-analyzed in relation to plant phytosociology because it is essentially similar to the other treatments. In relation to weeds occurrence, it was possible to observe a huge difference in infestation as a function of the source of dry mass covering the soil - shoot or roots of $B$. decumbens. When dry mass of shoot was used as cover crop, around $25 \%$ of the area was covered by weeds, while using dry mass of roots as cover crop allowed around $50 \%$ of coverage by weeds (Figure 1). The same was observed for number of weed plants per square meter (160 when shoot was used against, roots dry mass - Figure 2), and dry mass of weeds (6 and $8 \mathrm{~g} \mathrm{~m}^{-2}$ accumulated by weeds, respectively under coverage by shoot or roots of $B$. decumbens - Figure 3).

The Sørensen's similarity coefficient (QS), is a statistic used for comparing the similarity of two samples. However, for the biological concept this coefficient has the limitation of considering areas in relation to its composition, and not in terms of each species abundance. According to Felfili \& Venturoli (2000), similarity indexes above 50\% indicates 
high similarity between two compared areas exclusively in relation to plant composition. In general terms, the only lack of similarities were observed when comparing T5 x T2 and T5 x T6 (Table 7). This indicates that just a few years of distinct management between areas is not enough to promote changes at the soil seed bank in a way that the most problematic weed species are eliminated from the area. However, after a few years the distinct management would probably promote immediate changes at the composition of weed species at the soil surface - species not favored by the management would be present at the soil seed bank but would have to enter in a dormant or quiescent state, waiting for proper conditions for germination (Noldin et al., 2006).

Considering the weed composition as a whole, 18 weed species occurred at the trial, being the most important $B$. decumbens, $A$. hybridus and $D$. horizontalis, covering $40,74 \%, 21,29 \%$ and $9,16 \%$ respectively of the total area covered by weed plants; accounting for $39,26 \%, 25,36 \%$ and $7,36 \%$ respectively of the total number of weed plants and accumulating 47,65\%, 13,29\% and $11,43 \%$ respectively of the total dry mass accumulated by the community of weed species (Table 8).

Table 7 - Sørensen's similarity coefficients between treatments. Embrapa Western Region Agriculture, Dourados, MS, Brazil, 2010

\begin{tabular}{|c|c|c|c|}
\hline Comparison & Sørensen's coeff. & Comparison & $\begin{array}{l}\text { Sørensen's } \\
\text { coeff. }\end{array}$ \\
\hline $\mathrm{T} 1 \times \mathrm{T} 2$ & 0.55 & $\mathrm{~T} 3 \times \mathrm{T} 4$ & 0.87 \\
\hline $\mathrm{T} 1 \times \mathrm{T} 3$ & 0.80 & $\mathrm{~T} 3 \times \mathrm{T} 5$ & 0.70 \\
\hline $\mathrm{T} 1 \times \mathrm{T} 4$ & 0.82 & T3 x T6 & 0.76 \\
\hline $\mathrm{T} 1 \times \mathrm{T} 5$ & 0.63 & $\mathrm{~T} 4 \times \mathrm{T} 5$ & 0.82 \\
\hline $\mathrm{T} 1 \times \mathrm{T} 6$ & 0.71 & $\mathrm{~T} 4 \mathrm{x}$ T6 & 0.62 \\
\hline $\mathrm{T} 2 \times \mathrm{T} 3$ & 0.53 & T5 x T6 & 0.43 \\
\hline $\mathrm{T} 2 \times \mathrm{T} 4$ & 0.63 & & \\
\hline $\mathrm{T} 2 \times \mathrm{T} 5$ & 0.31 & & \\
\hline $\mathrm{T} 2 \times \mathrm{T} 6$ & 0.55 & & \\
\hline
\end{tabular}

Table 8 - Summary of weed species and its relative importance at Embrapa Western Region Agriculture, Dourados, MS, Brazil, 2010

\begin{tabular}{|l|l|l|r|r|c|}
\hline \multicolumn{1}{|c|}{ Scientific name } & \multicolumn{1}{|c|}{ Portuguese name } & \multicolumn{1}{c|}{ English name } & \% AC & \% Pl. \# & \% DM \\
\hline Acanthospermum hispidum & Carrapicho-de-carneiro & Bristly Starbur & 0.21 & 0.51 & 0.21 \\
\hline Amaranthus hybridus & Caruru & Slender Pigweed & 21.29 & 25.36 & 13.29 \\
\hline Ambrosia elatior & Losna & Short Ragweed & 2.16 & 2.04 & 1.29 \\
\hline Bidens pilosa & Picão-preto & Spanish Needle & 0.93 & 0.61 & 0.46 \\
\hline Brachiaria decumbens & Capim-braquiária & Signal Grass & 40.74 & 39.26 & 47.65 \\
\hline Brachiaria plantaginea & Capim-marmelada & Alexandergrass & 4.01 & 3.27 & 6.09 \\
\hline Chamaesyce hyssopifolia & Erva-andorinha & Hyssop Spurge & 1.13 & 1.94 & 0.92 \\
\hline Commelina benghalensis & Trapoeraba & Tropical Spiderwort & 1.23 & 0.41 & 0.88 \\
\hline Conyza bonariensis & Buva & Hairy Fleabane & 0.93 & 0.82 & 0.59 \\
\hline Digitaria horizontalis & Capim-colchão & Jamaican Crabgrass & 9.16 & 7.36 & 11.43 \\
\hline Echinochloa crusgalli & Capim-arroz & Barnyardgrass & 5.14 & 5.32 & 5.06 \\
\hline Eleusine indica & Capim-pé-de-galinha & Goosegrass & 1.75 & 2.86 & 1.30 \\
\hline Emilia sonchifolia & Falsa-serralha & Red Tasselflower & 1.75 & 0.51 & 1.17 \\
\hline Leonotis nepetifolia & Cordao-de-frade & Lion's Tail & 1.95 & 3.08 & 1.31 \\
\hline Portulaca oleracea & Beldroega & Common Purslane & 4.73 & 2.86 & 5.74 \\
\hline Richardia brasiliensis & Poaia & Brazil Pusley & 2.16 & 2.25 & 1.73 \\
\hline Sida rhombifolia & Guanxuma & Arrowleaf Sida & 0.41 & 1.23 & 0.53 \\
\hline Solanum viarum & Joá-amarelo & Tropical Soda Apple & 0.32 & 0.30 & 0.35 \\
\hline$------1 .-19$ & 100 & 100 & 100 \\
\hline
\end{tabular}

$\% \mathrm{AC}=$ proportion of area covered by the species in relation to the total area covered by weeds; $\% \mathrm{Pl} . \#=$ proportion of plants of the given species in relation to the total number of weed plants present; \% $\mathrm{DM}=$ proportion of dominance (based on dry mass accumulation) attributed to the given species in relation to the total dry mass of weeds at the trial. 
As a summary, the weed composition in the short term is influenced by the management of the area, but this shift requires some more years to be reflected at the soil seed bank. Some weed species occur in high densities and even this way they may not be the most serious weed species present in a given field. The most advised is to focus the management techniques to control the 4 or 5 most problematic. The continuous monitoring and crop scout will allow the farmer both to apply the chemical control at the right time and understand how the management is affecting the weed community in a given cropping system.

\section{LITERATURE CITED}

ANDREWS, D. J.; KASSAM, A. H. Importance of multiple cropping in increasing world food supplies. In: STELLY, M. (Ed.). Multiple cropping. Madison: ASA / CSSA / SSSA, 1976. p. 1-10. (ASA. Special Publication, 27).

BRAZILIAN agriculture: the miracle of the cerrado. The Economist On-line, London, 26 Aug. 2010. Disponível em: $<$ www.economist.com/node/16886442>. Acesso em: 15 Ago. 2010.

CORREIA, N. M.; DURIGAN, J. C. Emergência de plantas daninhas em solo coberto com palha de cana-de-açúcar.

Planta Daninha, v. 22, n. 1, p. 11-17, 2004.

FELFILI, J. M.; VENTUROLI, F. Tópicos em análise de vegetação. Comum. Técn. Flor., v. 2, n. 2, p. 34-44, 2000.

FERNANDEZ, R. et al. A study of the effect of interaction between site-specific conditions, residue cover and weed control on water storage during fallow. Agric. Water Manag., v. 95, n. 9, p. 1028-1040, 2008.

GHARINEH, M. H.; MOOSAVI, S. A. Effects of intercropping (Canola-Faba Bean) on density and diversity of weeds. Notulae Sci. Biol., v. 2, n. 1, p. 109-112, 2010.

HUGAR, H.Y.; PALLED,Y. B. Effect of intercropped vegetables on maize and associated weeds in maize-vegetable intercropping systems. Karnataka J. Agric. Sci., v. 21, n. 2, p. 159-161, 2008.
KLUTHCOUSKI, J.; AIDAR, H. Sistema Santa Fé. In: KLUTHCOUSKI, J.; STONE, L.F.; AIDAR, H. (Eds.). Integração lavoura-pecuária. Santo Antônio de Goiás: Embrapa Arroz e Feijão, 2003. p. 405-441.

LUZ, S. M. et al. Atividade alelopática de substâncias químicas isoladas da Acacia mangium e suas variações em função do pH. Planta Daninha, v. 28, n. 3, p. 479-488, 2010 .

MUELLER-DOMBOIS, D.; ELLENBERG, H. Aims and methods of vegetation ecology. New York: Wiley, 1974. $547 \mathrm{p}$.

NOLDIN, J. A.; CHANDLER, J. M.; McCAULEY, G. N. Seed longevity of red rice ecotypes buried in soil. Planta Daninha, v. 24, n. 4, p. 611-620, 2006.

PACHECO, L. P. et al. Sobressemeadura da soja como técnica para supressão da emergência de plantas daninhas. Planta Daninha, v. 27, n. 3, p. 455-463, 2009.

SEVERINO, F. J. Supressão da infestação da plantas daninhas pelo sistema de produção de integração lavoura-pecuária. 2005. $113 \mathrm{f}$. Tese (Doutorado em Fitotecnia) - Escola Superior de Agricultura "Luiz de Queiroz", Universidade de São Paulo, Piracicaba, 2005.

SILVA, A. A. et al. (Eds.) Tópicos em manejo de plantas daninhas. Viçosa, MG: Universidade Federal de Viçosa, 2007. p. $17-61$

SØRENSEN, T. A method of establishing groups of equal amplitude in plant sociology based on similarity of species and its application to analyses of the vegetation on Danish commons. Biol. Skrifter, v. 5, n. 4, p. 1-34, 1957.

TAIZ, L., ZEIGER, E. Plant physiology. Sunderland: Sinauer, 2006. 705 p.

TOWNSEND, C. R.; PEREIRA, R. G. A.; COSTA, N. L. Considerações sobre sistemas de integração lavoura/pecuária na Amazônia. Porto Velho: Embrapa Rondônia, 2009. 29 p. (Embrapa Rondônia. Documentos, 130)

VOLL, E. et al. A dinâmina das plantas daninhas e práticas de manejo. Londrina: Embrapa Soja, 2005. 85 p. (Embrapa Soja. Documentos, 260). 